\title{
Talking Time in Children's Adventure Fiction: Which Gender Controls the Discourse?
}

\author{
Elizabeth Poynter*
}

Leeds Beckett University, West Yorkshire, United Kingdom

Corresponding Author: Elizabeth Poynter, E-mail: E.Poynter@leedsbeckett.ac.uk

\section{ARTICLE INFO}

Article history

Received: February 20, 2018

Accepted: April 25, 2018

Published: September 01, 2018

Volume: 7 Issue: 5

Advance access: July 2018

Conflicts of interest: None

Funding: None

\begin{abstract}
It is nowadays widely agreed that gender identity is socially and culturally constructed. This construction is enabled by parental and other adult models, parental treatment, peer pressure and the media. Today television has a powerful impact, but in the mid-twentieth century books were more influential for many children. Did popular children's fiction of this period merely reflect society's bipolar gender constructs, or did it in any way challenge these? Whereas folklinguistics would suggest that females are more verbose than males, sociolinguists have found the opposite to be true in many contexts; public discourse such as meetings and the classroom tends to be dominated by males. There have been a number of studies of verbosity in real-life contexts; this cross-disciplinary study of four children's adventure books examines the discourse to see who is given the most 'talking time'. It was hypothesised that the authors would be influenced either by the folklinguistic view and give their girls long speech turns, or by the actual discourse they themselves experienced and give the boys the lion's share. The actual picture that emerges is far more complex, suggesting that while some writers did indeed reflect and support the accepted gender roles of the society in which they wrote, others created discourse which interwove gender, age and personality, with personality the most powerful factor in determining dominance.
\end{abstract}

Key words: Gender Roles, Children's Fiction, Dominance, Verbosity, Talking Time

\section{INTRODUCTION}

This study crosses the boundaries between linguistics and literature. It uses the sociolinguistic concept of verbosity or 'talking time' to analyse selected texts of children's adventure fiction, with the aim of determining whether dialogue in such texts reflects the gender norms of real-life discourse, those of popular mythology, or neither of these.

\section{Language and Gender}

In 1997 Schlegoff suggested that gender should only be the focus of discourse analysis in cases where it is made salient by the participants. As Weatherall (2011) points out, however, gender is extremely pervasive in human interaction, and not always recognised by participants as a factor, so this principle is too extreme. The study of the relationship between language and gender really only began in the 1970s with the development of sociolinguistics; prior to that there had tended to be assumptions made without firm data and certainly without examining the concept of gender itself. Otto Jespersen in 1922 only dedicated a single chapter of his book Language: Its Nature, Development and Origin to 'The woman', and he claimed women had a smaller vocabulary than men (possibly true in view of the then inequalities in education) and were more verbose. This last claim is pure folklinguistics, but is still widely believed by the general public (Coates, 2004).

Robin Lakoff's 1975 book Language and Woman's Place is often cited as having begun a serious academic interest in how gender and language interact. Her model, like Jespersen's, was based more on intuition than solid data and has consequently received a great deal of criticism, but unlike Jespersen she did not assume that women's language was 'naturally' different but sought cultural explanations, and this view inspired much valuable work.

In the 1980s and '90s two models emerged: the 'dominance' model (e.g. Spender, 1985; West and Zimmermann, 1983) which held that language reflected the hierarchical nature of society and male dominance, and the 'difference' model (e.g. Tannen, 1986) which proposed that males and females operate differently in society and their language use reflects that. Both of these views support the basic hypothesis that the nature of society determines language use.

More recent approaches incorporate the concept of gender fluidity. As Järviluoma et al. (2003) said, it is important to analyse the concept of gender itself, rather than assume we know what it is, which previous approaches had done. However, as Garfinkel remarked as long ago as 1967 (cited in Cromdal, 2011: 294), there is a strong tendency to understand human behaviour in terms of (two) gender categories. The more widespread and deep-seated this tendency, the 
more it is likely to be self-reinforcing; if Jane and Susan like pink and speak politely it will be assumed they do so because they are girls, and Annabel will be encouraged to behave similarly because she is also a girl, and that's what girls do.

\section{Verbosity or 'Talking Time'}

Whether one buys into the concept of 'dominance' or prefers a more nuanced approach, it cannot be denied that there is a considerable body of evidence suggesting that males tend to hold the floor in public discourse in Western societies, at least. This contradicts the folklinguistic assumptions referred to in 1.1 above. A number of studies have found, for instance, that men tend to interrupt women more than the reverse (Zimmermann and West, 1975); that boys talk more in class than girls (Sadker and Sadker, 1985), and that both the girls and the teachers are complicit in this; similarly in the home, with family discourse round the dinner table the anecdotes are largely told by the males, father and sons (Erickson, 1990); male TV interviewers talk more than female ones (Holmes, 1995); even in supposedly female-friendly email discussion groups, if there is a day when women post more than men, the men are likely to claim they are being 'silenced' and threaten to unsubscribe from the network (Herring et al, 1998). In 1980 Dale Spender famously hypothesised that the myth of the talkative woman arose because we have different expectations of males and females, the latter being measured against silence, rather than against men. In 1979 she had suggested women could occupy a maximum of $30 \%$ of the talking time before it would be perceived as ‘too much' by men (cited in Coates, 2004: 118).

\section{Developing a Gender Identity}

Children develop their gender identity through a multiplicity of influences, including parental behaviour, parental models, peer pressure and the media (Franklin, 2012). Nowadays television and video games are likely to be more powerful than books. Lamb and Mykel Brown (2006: 75) report on studies which show that children who watch a lot of television have more stereotypical views than those who do not, and fourth and fifth graders who watch a lot are more likely to gender-stereotype household tasks. However, in 1930-70, my period of study, this was not the case; television was only becoming popular towards the end of this time, and books were likely to have been a more powerful influence. A weak view of the relationship between language and gender would hold that language use reflects society; a strong one that language actually creates and sustains gender divisions (Talbot, 2010: 15). A literary text is, clearly, different from real-life discourse, yet literature is an aspect of the language children experience. As Stephens has pointed out:

Texts for young audiences are not mere narratives, but have an orientation towards models and ideologies already present in culture and, by giving these narrative form, may reinforce them and refract them back to the culture or may propose some modification of them (2002: 40).

In the $1930 \mathrm{~s}$, gender roles in Britain were still very traditional, although the professions were beginning to open up to women; in the 1931 census there were 2,830 female doctors, for example, as compared with only 477 in 1914 (Pugh, 2008). Women were routinely paid less for the same jobs, government policy dictated that girls should study Domestic Science twice a week, and although the Second War brought some opportunities, post-war Britain wanted women to return to the home to boost the population (ibid.). By 1970, works such as Simone de Beauvoir's The Second Sex (1949) and Betty Friedan's The Feminine Mystique (1963) were having an impact on the feminist movement (LeGates, 2001), but for many people in Britain it was still true that, as Arthur Marwick wrote of the 1950s, "The basic assumption in all classes was that girls would become wives and mothers, and should therefore be treated accordingly" (2003: 47). Did the books children read largely reinforce this model, or did they "propose some modification" of it?

\section{THIS STUDY}

\section{Context of the Study}

In carrying out a study of gender roles in British children's adventure fiction in the mid-twentieth century (Poynter, 2018), I hoped to see whether popular children's fiction of the time did, as critics have generally claimed, merely reinforce the socially-accepted gender roles of the day. The full study entailed 126 principal texts by seven authors ( 65 books by four female writers, and 61 texts by three male writers) and examined various aspects of gender. The study reported here (which picks up and expands some of the work in the full study) lies across the boundary between linguistics and literature: I am not looking at what real children say or said but at what their authors made their male and female characters say. Yet this would have had an impact on real children and quite possibly influenced their actual discourse.

I wondered whether the language use would reflect the authors' (probably folklinguistic) views of language and gender, or the actual use they had subconsciously imbibed from the world in which they had developed their own gender identities. Specifically, in relation to 'talking time', would they demonstrate the popular view that females are more verbose than males, or would they reflect the fact revealed by numerous studies that males tend to dominate discourse, especially around demonstrating knowledge and making decisions. Most of the evidence cited above dates from several decades ago; however, there is little evidence that the balance of verbosity has changed significantly, and in any case, my primary texts date from even earlier. The books were published and set in the mid-twentieth century, and some of the authors had been born in the nineteenth.

The four authors selected for this study of verbosity were: Arthur Ransome (1884-1967), Enid Blyton (1897-1968), Malcolm Saville (1901-1982) and Gwendoline Courtney (1911-96). In each of the themes which emerged from the full study, including female agency, adult roles, and leadership and power, there was a range from the stereotypical and conservative to the open and innovative. With some exceptions, the works of Enid Blyton tended to fall into the former, and those of Arthur Ransome into the latter category. Certainly 
it is true to say that Blyton was the most conservative of the female writers, and Ransome probably the most progressive of the males. He was also the most directly comparable with Blyton as regards the ages of his protagonists. As one aspect of my linguistic analysis, therefore, I initially selected one book by each of these authors for a study of 'talking time'. Courtney and Saville each have slightly older protagonists, mostly teenagers; Courtney's works provide a wide range of positive female role models in terms of agency and leadership, and Saville additionally offers a variety of masculinities.

\section{Method}

The texts selected were Swallowdale (first published 1931), the second in Ransome's Swallows and Amazons series; Five Go Adventuring Again (1943), the second in Blyton's Famous Five series; The Secret of Grey Walls (1947), the fourth of Saville's Lone Pine series; and Courtney's Mermaid House (1953). In focusing on talking time, I first skimmed the texts and decided to divide the characters' speeches into 'short' and 'long' turns, defined as up to three lines of text, ('short'), and over three lines of text ('long'). The three lines might include narrative devices such as 'said Julian', but not cases where whole sentences of narrative interrupted a speech. This distinction was based on the fact that speeches where the speaker dominated the conversation by giving orders or instructions or relating an anecdote tended to be more than three lines of text. In rare cases where a character's long speech was separated into paragraphs, each paragraph was counted as a long utterance, but few speeches were as long as that. Once the basic definition had been determined, it was applied initially without further analysis of the specific purpose of individual speech turns in order to obtain a raw number.

Only speeches by the child protagonists were counted. In the Blyton book this meant Julian, Dick, George (Georgina) and Anne. In the Ransome book it meant the four Swallows, John, Susan, Titty and Roger, and the two Amazons, Nancy and Peggy. Already therefore we have a clear distinction between these two authors: Blyton has, as is typical of her other adventure series also, two boys and two girls, with the eldest a boy and the youngest a girl. Ransome has a family of two boys and two girls, of which the boys are the eldest and youngest, plus a second family of two girls, leading to a female majority, which is never encountered in Blyton. This particular Saville book was chosen because it features all eight principal Lone Piners, four boys and four girls, six of whom are teenagers and two are ten-year-old twins. Courtney's book has a family of four, two boys and two girls, plus another local girl and boy who join them in the adventure. Her books are more varied in their gender mixes: several have girls and only one boy, which I felt would not give a sufficiently clear picture.

\section{FINDINGS}

\section{Blyton}

In the Blyton book, the total numbers of short and long speech turns are shown in figure 1. There is a marked

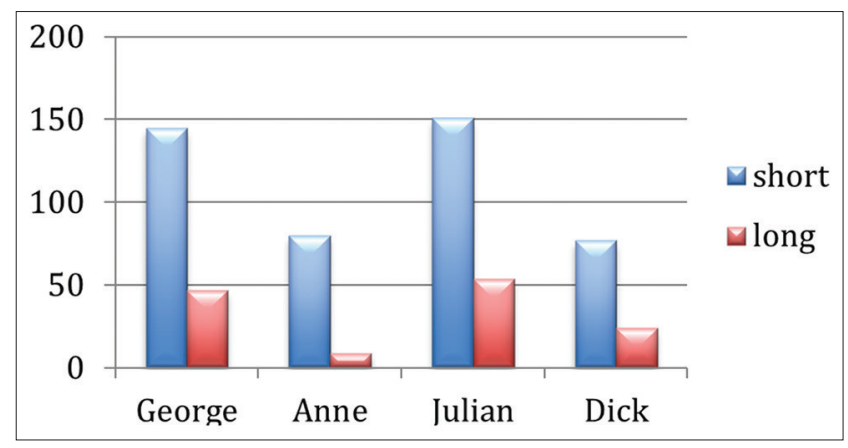

Figure 1. Pattern of short and long utterances in Blyton (Poynter, 2018: 135)

difference between Julian and George on the one hand, and Dick and Anne on the other. It appears at first glance that the discourse is not dominated by one gender or the other. If we consider only the long turns, Dick's share increases slightly, but the overall picture remains.

However, numbers alone cannot tell the whole story. As Joan Swann (2011) has pointed out, it is not sufficient merely to count the number of occurrences of a language form; one must look at function in context. A detailed examination of the text shows entirely different discoursal functions for Julian and George. Julian is the eldest and is explicitly recognised as the leader throughout the series, by both the children themselves and by interested adults such as his uncle, George's father. Many of his speeches are concerned with giving instructions and making decisions. For example, when the children are looking behind a secret panel Julian takes first turn and tells the others off for pushing him: “'Don't,' said Julian impatiently. 'Wait your turn, sillies! Let me have a look"' (39); and later, when they have found an old linen map inside the panel: "WWe'll have a good old puzzle over this piece of linen after dinner,' said Julian. 'I bet we'll find out what it says, if we really make up our minds to!'” (47). He even gives orders to the adults on occasion: “'Don't bother Anne,' he said to the grown-ups. 'If she thinks she can't tell you, she's got some very good reason."' (119). And his manner to George, who is only a year younger than him, is more like that of a father: "'Good girl!' said Julian. 'Now here he comes - so do your best."” (103).

George in all the Famous Five books is portrayed as difficult, hot-tempered, sulky and always struggling with being part of a group, having been brought up an only child. Her insistence on being addressed and treated as a boy is part of her individuality and inability to conform. In this book in particular she takes a dislike to the tutor her father has hired and is angry and defiant. Many of her speech turns relate to this. Early in their acquaintance the tutor comments that her beloved dog, Timmy, is "queer-looking": "George went purple in the face. 'He's not queer-looking!' she spluttered. 'He's not nearly so queer-looking as you! He's not a terrible mongrel. He's the best dog in the world!'” (53) Later, when the tutor has insisted that the dog sleep outside in his kennel rather than in her room, and refused to relent despite her attempts at good behaviour: "“Oh, what a beast he is!' she cried. 'How I do hate him! I'll pay him out for this. I will, I will!"” (108). 
Julian is the leader and he dominates the discourse. Dick is younger and therefore has less power, but as we saw in figure 1, his share of the longer turns is markedly larger than that of his little sister, Anne. That is, he is behaving like a 'second-lead', and his longer turns mostly involve him suggesting courses of action and giving instructions. Anne is the stereotype of a good little girl, obedient and domesticated, sensitive and easily frightened, in need of her brothers' protection; she has a small share of the short turns (general chatter) and a very small share of the long turns (decision-making, anecdote narration).

George, with a share of the discourse comparable to that of Julian, is anything but a typical girl. Throughout the books, Blyton demonstrates an ambivalent attitude to George: she is skilful (she swims and rows if anything better than her male cousins), truthful and brave, but she often behaves badly and provokes anger in adults and exasperation in her cousins. My study of modifiers in Five Go Adventuring Again (Poynter, 2018) provided overwhelmingly more negative than positive descriptions of George ('awkward', 'sulky', 'disobedient', 'defiantly', 'scowled' etc.). Yet in fact she is right to dislike and distrust the tutor, who proves to be in league with the villains, and time and again in the series it is George whose courage and initiative save the day.

\section{Ransome}

Swallowdale is a considerably longer book than Five Go Adventuring Again, and was more complex to analyse as of its 36 chapters the Amazons only appear in 17, and several other chapters feature only Titty and Roger when they go off and have an adventure by themselves. It was therefore necessary, after counting the total number of speech turns, to normalise these data, at least approximately, using the number of chapters in which each character appeared as a proportion of the whole. The results are shown in figure 2, while figure 3 shows the proportion of long speech turns for each child.

Among the four Walker children (the Swallows), there is, as in Blyton, a division with a girl and a boy on each side: John and Titty are considerably more dominant as regards talking time than Susan and Roger. The reasons for this are somewhat different from Blyton's, however. John is indeed comparable to Julian in the Famous Five: he is the eldest, a boy, and is explicitly recognised as the leader. Yet Ransome's children have a far more detailed hierarchy than Blyton's, using naval ranks. Of the Swallows, John is the captain, Susan the mate, Titty the able seaman and Roger the ship's boy. Therefore when the two youngest go off together, Titty becomes the leader by virtue of her superior rank. Roger as the youngest contributes almost as many short turns as John, but far fewer long ones; Susan, on the other hand, is less chatty (few short turns) but does exercise authority in relation to domestic matters such as bed and meal times, and fire-making. Long speech turns in Ransome seem to be an indication of authority and power.

There are other factors which should be taken into consideration. Titty is the most imaginative of the children, and while some of her long turns are indeed related to the

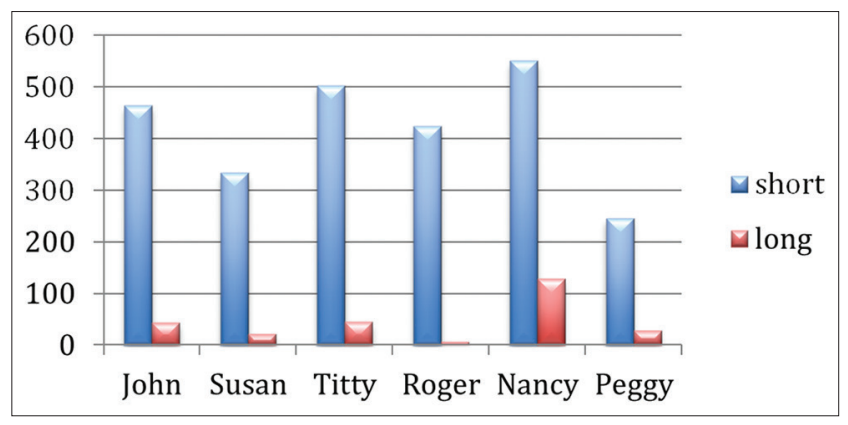

Figure 2. Normalised data for Ransome's children (Poynter, 2018: 137)

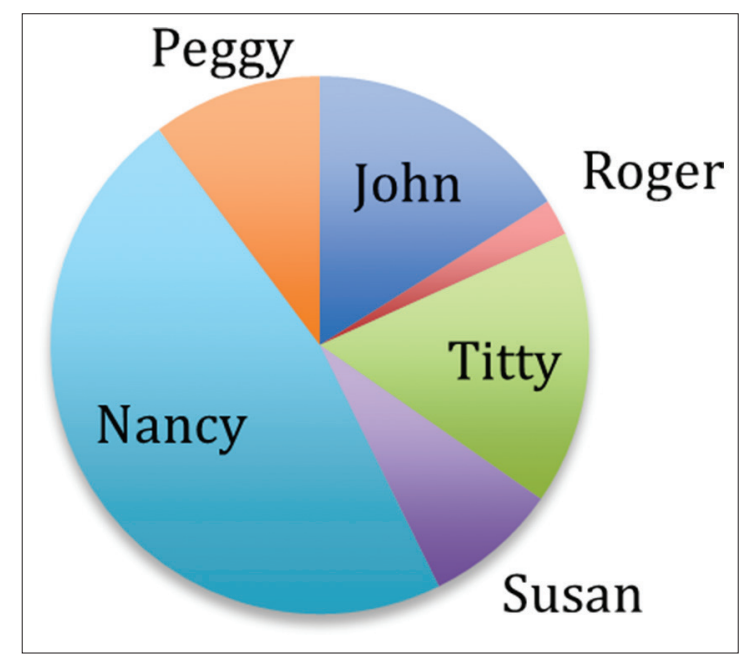

Figure 3. Proportion of long utterances in Ransome (Poynter, 2018: 137)

exercise of power when she and Roger are together without the older children, others involve her giving rein to her imagination. In this book, this often relates to the imaginary character Peter Duck, a kindly elderly sailor who appears in the metafictional story named after him:

'Come on,' said Titty. 'We'll go and fetch the captain and the mate. We'll leave Peter Duck to look after it till we come back. It's his cave. I expect he's known about it always. Come on.' (64);

'We could put Peter Duck on guard,' said Titty. 'We could live in our tents and supposing we saw an enemy coming we could hide everything in the cave and no one would ever know where our stronghold was. It's a great place.'

'It's a pity we haven't got any enemies,' said Roger.

'We may have lots.' said Titty (152).

When the Amazons are taken into account, it appears that perhaps Ransome does express the notion that females talk more than males, as Nancy has more short turns than anyone else and considerably more long ones. In fact, however, this is a further demonstration that his talking time relates to power; Nancy has more authority than anyone else. Like John, she is a captain, but where he is rather reserved, and sometimes afraid of making a fool of himself, she is confident and tends to take command in any situation, not just on board her own boat. It might be suggested that in Nancy 
Ransome is combining the talking time which derives from power, usually reserved for males, with the talking time popularly attributed to females, but a glance at the profiles of Susan and Peggy does not support the argument that he believed all females talked a lot.

A further aspect of power is expertise. Leet-Pellegrini (1980, cited in Coates 2004: 109) studied the relationship between expertise and gender in relation to conversational dominance. In doctor-patient dialogues, the doctor (= 'expert') tended to dominate except in cases where the doctor was female and the patient male, that is to say gender was more salient than expertise, but expertise was also a factor. O'Barr and Atkins (1980) found that expertise was the principal determinant of use (or non-use) of hedging language by witnesses in a courtroom. In many of Ransome's books, Nancy is in the position of 'expert', either because she is particularly good at an activity, such as swinging the lead in Great Northern?, or in this book because she and Peggy live locally whereas the Walker family are visitors to the area. The Amazons guide the Walkers up a local mountain during the course of this book. Thus in addition to her role as captain of a boat, Nancy has a dominating personality and the expertise of local knowledge all contributing to her authority, reflected in her talking time.

\section{Saville}

In most of Saville's Lone Pine books we meet the three Mortons, David (fifteen in the first book, here sixteen) and the nine-year-old twins (later ten), Dickie and Mary; Peter (Petronella), David's girlfriend, and then either cousins Jon and Penny Warrender or friends Tom and Jenny: in this book all eight are together. I selected this book because I wanted to see the interplay of individual character with gender (and possibly age). David is officially the captain of the Lone Pine Club but in most of the books decisions tend to be mutual among the older members, and he is not portrayed as bossy. He frequently fails, in fact, to keep his twin siblings under control. Peter is described as quiet, reserved and uncomfortable with strangers. Penny and Jenny are both redheads and described as talkative ("Penny, who was a very good talker under any circumstances, gazed in mute admiration at the way in which Jenny, apparently without taking breath, switched from one romantic and thrilling story into another": 110); Penny is strong-willed and daring, Jenny is easily scared, and very romantic. Jon is bespectacled and intellectual, and tends to be rather superior with the younger ones, while Tom is primarily a man of action.

Figure 4 reveals that the author's descriptions are not necessarily borne out by the balance of the discourse turns. David seems to be much more in control than one would expect from his rather calm, laid-back character. Peter, the oldest of the girls and vice-captain of the club, does not bear out the description 'quiet'. Jon also says a good deal more than one is led to expect: "Jon.made one of his rare remarks" (126). Penny is indeed talkative, but then Penny is also, as I have said, strong-willed and determined. Many of her speech turns involve her driving or attempting to drive the action:

'Listen, Peter,' she said as she tossed back her curls. 'I know what we must do and it's the only thing we can do. I'm not going down to the police station for anybody and I don't care if Mr. Cantor is the Lord-High-Detective of all England!.Here we have been sitting mugging round the fire waiting for the boys, and then for Agnes to do something. Why don't we do something? Let's jolly well go out now on our own. Let's go to Grey Walls and explore that and see if we can see any sign of them.' (231).

Tom and Jenny have very much less to say than the others. Jenny's chatterbox nature is demonstrated by her long speech turns (she is the only one whose long turns actually outnumber her short ones), which are breathless and long-winded:

D'you know, David, that I really was here first? I was here before Tom even, and he told me that's he's hurried on specially. It was your map that did it, David. D'you know that I understood it nearly all and I didn't lose my way once.And another thing, David. Dad says I can stay just as long as you'll all have me, and I'm so excited I just don't know what to do next. Oh, hullo, you twins! Sorry not to say it before, but I did see you... Hullo, Mackie! Isn't he a pet, Mary?. (62)

Yet her overall share of the discourse does not support this.

The twins are very strong characters who impose themselves on the plot. Acting together, they frequently end up in

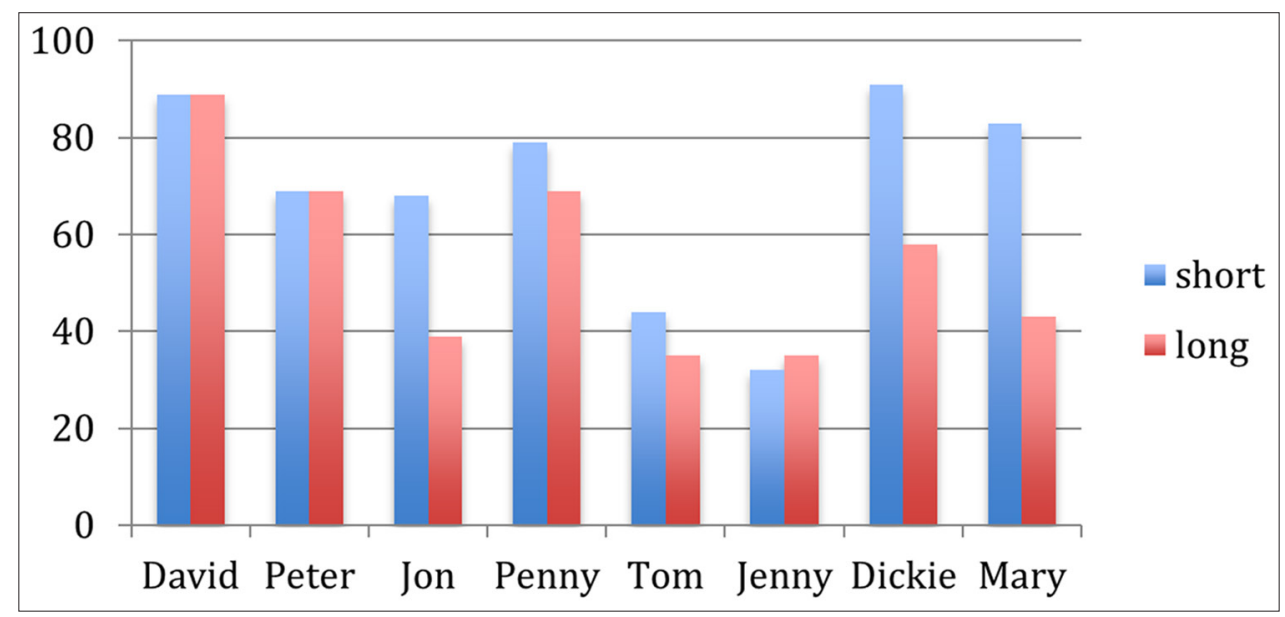

Figure 4. Speech turns in Saville's The Secret of Grey Walls 
trouble, often getting caught by the villains thanks to their intrepidity. In this book they vociferously complain about being left out of a midnight adventure by the others, they are the ones to identify a mysterious cyclist who has been following them, and they then spend a whole day distracting this man (he is actually a detective) so that the others can investigate without him following them. In different books each is referred to as 'the leader', and overall the impression is given that Mary is a little more mature and has more initiative, yet here we see that Dickie actually talks more. They both have a substantially larger part than Tom and Jenny. Like the youngest in the other books they have a larger proportion of short-to-long utterances than the older characters; they impose themselves by frequent short speeches more than long ones. Unlike Anne in Blyton and Roger in Ransome, however, they also have more long utterances than several of the older children.

Although Saville pays lip service to the concept of female verbosity with his characters Penny and Jenny (none of the boys is described as garrulous), what we see in practice is speech turns going to the powerful. David, the 'captain', seems to have the most power, but this is shared by Peter, who though reserved is a strong character with many skills

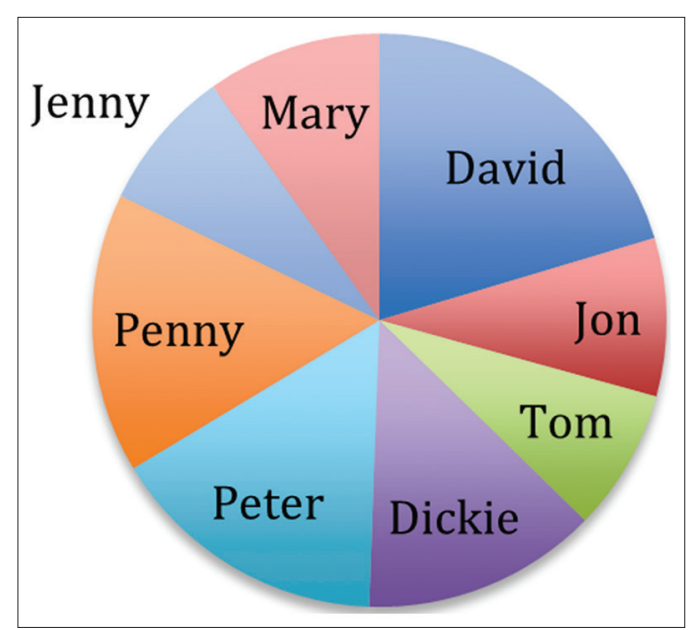

Figure 5. Long speech turns in Saville. and great courage, explicitly admired by the others in many of the books, and Penny. Penny is a talkative female, but so is Jenny, and their shares are by no means equal; Penny wins out by being a much stronger, bolder character. The young twins also seize power for themselves by refusing to obey the others or, as in this book, insisting on playing an important role. Thus Saville gives dominance neither to the males (boys and girls have an almost equal share of the long turns, as figure 5 shows) nor the eldest, although these two factors play a part with David, but primarily to the strong personalities.

\section{Courtney}

In this book, the four Greystone children (Giles, seventeen, Fay, fifteen, Anthony, fourteen and Peggy, twelve) are in almost every chapter (Peggy stays at home at one point, and Fay is kidnapped and therefore separated from the rest for a couple of chapters), but the locals, Agnes the squire's daughter and Ned the fisher boy, only appear in about half the book. I have therefore normalised these data as I did with Swallowdale. Figure 6 shows the pattern of short and long utterances for the six children, and figure 7 the long utterances.

It is immediately clear here that the two older girls are the most talkative. Giles is the eldest, and he does demonstrate a sense of responsibility for his siblings (".take Pegs with you. We mustn't leave her alone again": 145) but he seems rather quieter than Fay. Anthony, who is portrayed as bespectacled, thoughtful and widely-read, has fewer short speeches yet more long ones than either. He is intelligent and works things out. Agnes, however, has the lion's share of the long speeches. This is chiefly because she possesses knowledge which the others, who are new to the area, do not have. Her father has disappeared and the others agree to help her find him; she knows the local people and the local geography; and in particular, she knows the secret passages which play a major role in the plot. In places she speaks for more than a page, with the odd interjection from one of the others to break up the text. However, her speeches are by no means limited to giving information; she also makes decisions and gives orders:

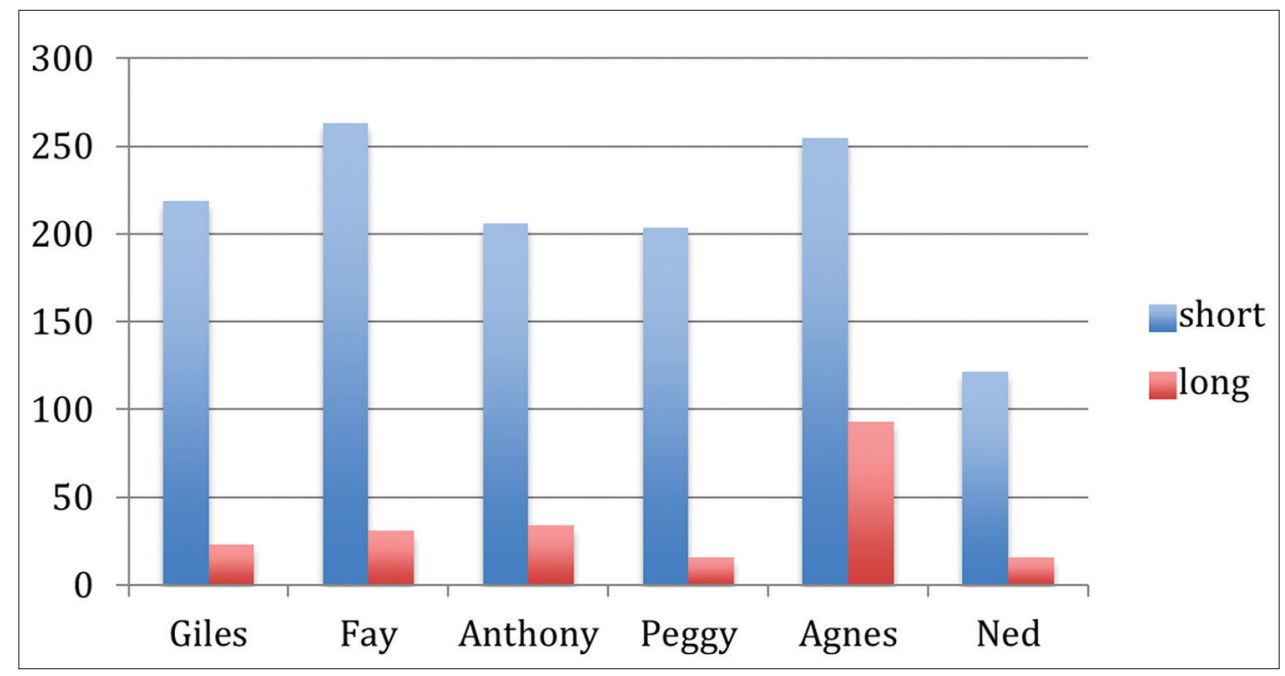

Figure 6. Long and short utterances in Courtney's Mermaid House, normalised 
... If I can get into the cave early - there must be somewhere in the boat I can hide. Now listen! One of you must go back and tell Giles to meet me the moment it's dark, and the other must go and find Ned, and tell him all that's happened, and that he's to meet me, too (150-1).

It seems that class, rather than gender, comes into play in Agnes' relationship with Ned; her father is Dr Morvyn, a scholar and owner of the local 'big' house, while Ned is working-class and loyally does her bidding. Although he is in almost the same proportion of the book, eleven chapters to Agnes' twelve, he has half as many short speeches and only a tenth as many long ones. His main function is to listen and act.

Peggy, the youngest, talks more than Ned but mostly in short utterances. Superficially, this looks like Roger in the Ransome book, yet Peggy is full of initiative and does suggest actions to the others. For instance, when the children need to search the house in case Fay has been hidden in it, it is Peggy who has the idea for a diversion to get their aunt out of the way: "I know! Leave it to me, and then you slip in and search quickly" (152). She is a strong character who

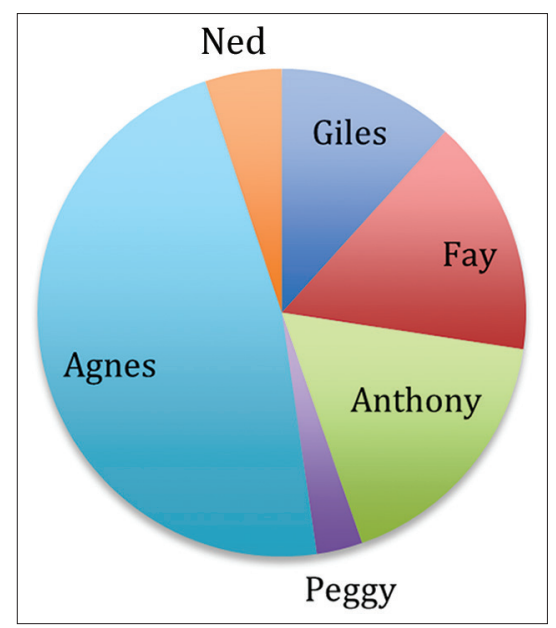

Figure 7. Long utterances in Mermaid House takes a full share in every conversation, unlike Anne in the Famous Five, but, like the other youngest characters, usually in short utterances.

\section{Comparing the Four Authors}

One point which did become apparent during my analysis was that the four authors had very different approaches to representing dialogue. Figure 8 shows the pattern of long speeches as a proportion of total number of utterances for each character, and it is immediately clear that all Saville's children are much more verbose than any of the others. In Blyton, the boys and the pseudo-boy, George, stand out as dominating over Anne, the youngest and the feminine girl. In Ransome Nancy and in Courtney Agnes are prominent: in each case a girl who has personality plus local knowledge and other expertise (sailing for Nancy, swimming for Agnes) to give her authority. In Saville everyone tends to deliver long speeches, even those with a relatively small share of the dialogue, Tom and Jenny. The result, in my view, is somewhat unnatural; as a child I was never wholly convinced by Saville's characters.

\section{DISCUSSION}

In real life, even decades after these books were written, discourse involving both genders has tended to be dominated by males. Males display their knowledge and make decisions, and females, both women and girls, are often complicit in this dominance. The first two authors were both born in the nineteenth century, Blyton in 1897 and Ransome in 1884, and brought up by parents with fairly traditional roles, their mothers acting chiefly as homemakers. When Blyton was in her teens her father deserted the family, in fact, and she herself not only trained as a teacher and always worked for a living, she frequently prioritised her work over her husband and daughters. Yet in her writing she consistently displays families where the father is the (usually rather dis-

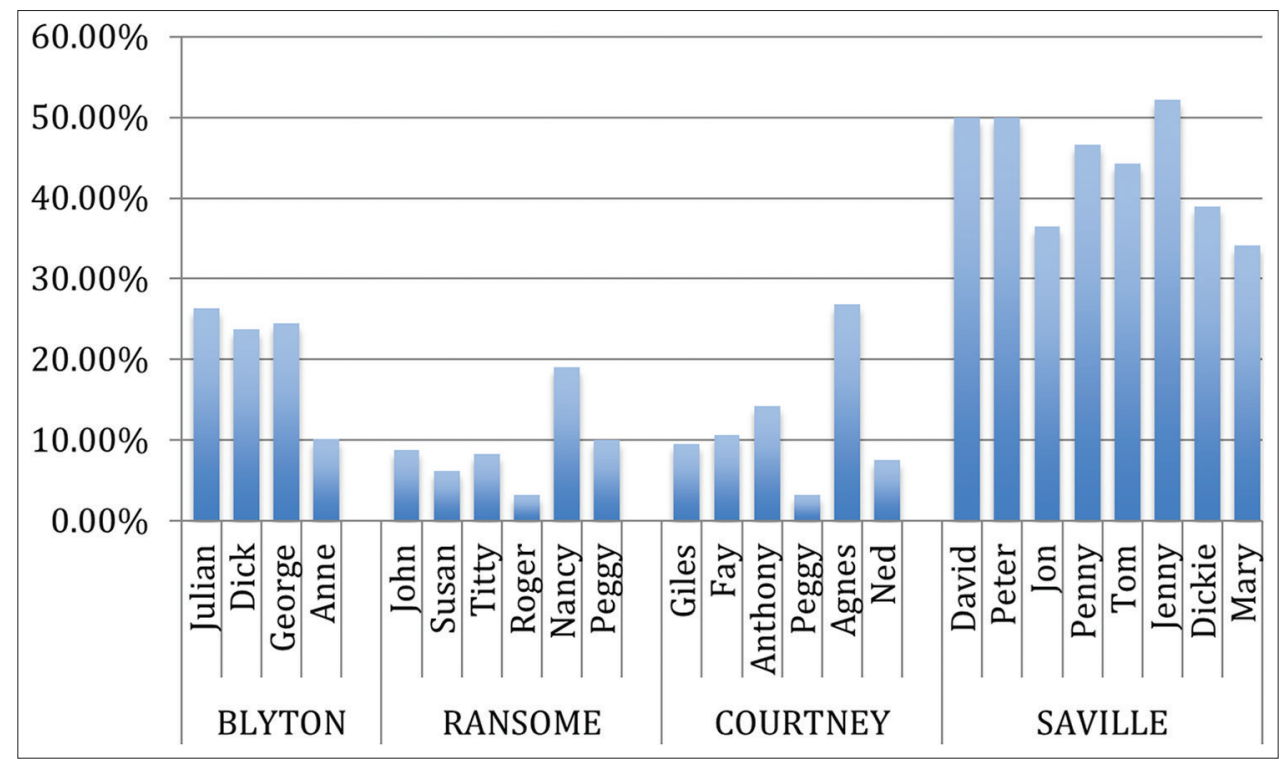

Figure 8. Long speeches as a proportion of the total dialogue 
tant) breadwinner and the mother is a housewife, and among her groups of child protagonists the leaders are always the boys, and the sweet domesticated girls are portrayed positively, while tomboys like George are largely praised for the extent to which they emulate boys (their skills, their courage) yet also criticised for being hot-tempered or sulky. They are admired but not loved. It is as though she felt the need to introduce characters who more nearly resembled herself than the good little girls did, yet at the same time had to present them quite negatively; they had no real place in the stereotyped adult world of kind stay-at-home mothers and strong authoritative fathers which lies in the background of all her children's adventures. This ambivalence perhaps explains why she gives so much talking time to George. On the one hand, she must secretly have sympathised with her (she claimed George was based on herself: Stoney, 1986), and on the other, she was explicitly preaching the conservative doctrine of the governments of the day.

Arthur Ransome was very much his own man. Living in Russia at the time of the 1917 Revolution, he opposed British government policy and attempted to persuade it to recognise the Bolsheviks. It is perhaps not surprising therefore that his books do not, in many respects, reflect the prevailing gender stereotypes, although it must be acknowledged that his adults are more similar to Blyton's. Nancy is perhaps akin to George, a tomboy accepted as such because she is adolescent but who will one day have to conform to feminine behaviour and fit in. If so, it is a far more subtle portrait. She does not wish or claim to be a boy, and no-one ever suggests that she does things 'as well as a boy'. She is simply widely respected for her skills by all the other children, with no reference to her gender. In Ransome, talking time seems to relate primarily to authority, regardless of gender: although three of the four with more long turns are female, this is not about chatter and gossip. Those with the most authority are John, captain of the Swallow, Susan, the mother figure who lays down the law about domestic issues, Titty over her younger brother by virtue of her rank (rank being determined by age), and above all Nancy, who is probably the oldest, captain of the Amazon, a local expert, and a dominant personality to boot.

Courtney was primarily an author for girls. She produced a number of 'family' books, and three of her thrillers are set in girls' boarding schools. It is not surprising therefore that she should give some of her girls dominant characters; in a typical girls' book there will be a range of personalities including both weak and strong. In particular she tends to have girls who are athletic: excellent climbers, the best shot, or in this book, outstanding swimmers. Fay and Agnes brave dangerous currents to swim out to a cave at midnight to spy on the criminals, and later when she and Giles go to rescue her father and Fay from a secret vault on an island and get trapped themselves, Agnes saves the day by swimming out and opening the vault from the other side. On the other hand, Blyton also wrote girls' school stories featuring a variety of strong characters, yet in her mixed-gender adventure fiction, the boys are always dominant.

Saville shares the action fairly equally among his boys and girls (the girls rescue the boys at least as often as vice versa, for example), but he does subscribe to the view that girls are more sensitive and must be pretty, conforming with traditional gender expectations. He explicitly describes his two redheads as talkative, which fits with this view, yet in practice overall the long turns are fairly equally shared between the boys and the girls, and what he seems to be doing is giving discourse dominance to the strongest characters, namely David, Peter and Penny, plus the young twins.

\section{CONCLUSION}

Verbosity has been much studied by sociolinguists, and this paper applies the concept to children's literature. As Jennifer Coates has said, "Language is an important part of the socialisation process, and children are socialised into culturally approved gender roles largely through language" (2004: 169). They meet this language from their parents, their teachers, their peers and the media. In Britain in the mid-twentieth century, "culturally approved gender roles" were strongly polarised, despite decades of the women's movement, universal suffrage and education. Men still basically controlled all aspects of public life, and boys were brought up to expect to do the same, while women, even those who achieved higher education and careers, were expected to see the roles of (supportive) wife and mother as their ultimate goal. Popular fiction would logically portray these distinct gender roles in a positive light as part of the socialisation of children. If so, one would expect that 'talking time' would either reflect the supposed verbosity of girls, chattering endlessly about not very much, or the actual conversational dominance of boys.

These four authors reveal a more complex picture. Enid Blyton explicitly makes her boys the leaders, telling the girls what to do, and her 'talking time' matches this, with the boys, especially the eldest, dominating the talk. Ransome and Saville seem at first sight to blend male dominance with female chatter, but a close examination of the actual discourse shows that the prominence of some of the female characters is due more to their possession of authority than to a tendency to gossip. Some of their girls (Nancy, Penny) seem more vivid than any of their boys, and they dominate by force of personality. Courtney also, less surprisingly perhaps as she is primarily a writer for girls, gives powerful roles to her female characters.

It does not appear from this small study that popular fiction was merely echoing the "culturally approved" roles of the day. Indeed, bearing in mind that Lamb and Mykel Brown reported in 2006 that "[ $\mathrm{t}]$ here are many more male lead characters on little kid TV" (59), it is interesting that fifty years earlier some popular writers seem to have been more progressive.

\section{REFERENCES}

Blyton, E. (1967) Five Go Adventuring Again. Leicester: Knight Books

Coates, J. (2004) Women, Men and Language $3^{\text {rd }}$ ed. Harlow, England: Pearson Longman

Courtney, G. (2011) Mermaid House. Coleford: Girls Gone By Publishers 
Cromdal, J. (2011) Gender as a practical concern in children's management of play participation. In S.A. Speer and E. Stokoe (eds) Conversation and Gender (pp. 294309) Cambridge: Cambridge University Press

Erickson, F. (1990) The social construction of discourse coherence in a family dinner table conversation. In B. Dorval (ed) Conversational Organization and its Development (pp. 207-38) Norwood, NJ: Ablex

Franklin, L. (2012) Gender. Basingstoke: Palgrave Macmillan

Herring, S., Johnson, D. and DiBenedetto, T. (1998) Participation in electronic discourse in a 'feminist' field. In J. Coates (ed) Language and Gender: A Reader (pp.27-46) Oxford: Blackwell

Holmes, J. (1995) Women, Men and Politeness. London: Longman

Järviluoma, H., Moisala, P. and Vilkko, A. (2003) Gender and Qualitative Methods. London: Sage

Jespersen, O. (1922) Language: Its Nature, Development and Origin. London: Allen and Unwin

Lakoff, R. (1975) Language and Woman's Place. New York: Harper and Row

Lamb, S and Mikel Brown, L. (2006) Packaging Girlhood. Rescuing Our Daughters from Marketers' Schemes. New York: St Martin's Press

Legates, M. (2001) In Their Time: A History of Feminism in Western Society. London: Routledge

Marwick, A. (2003) British Society since 1945, $4^{\text {th }}$ ed. London: Penguin Books

O’Barr, W. and Atkins, B.K. (1980) 'Women's language' or 'powerless language'? In S. McGonnell-Ginet, R. Borker and N. Furman (eds) Women and Language in Literature and Society (pp. 93-110) New York: Praeger

Poynter, E. (2018) You Girls Stay Here: Gender Roles in Popular British Children's Adventure Fiction, 1930-70. Newcastle: Cambridge Scholars Publishers

Pugh, M. (2008) We Danced All Night: A Social History of Britain Between the Wars. London: Vintage Books
Ransome, A. (1968) Swallowdale. London: Penguin

Sadker, M. and Sadker, D. (1985) Sexism in the schoolroom of the '80s. In Psychology Today, March, 54-7.

Saville, M. (1947) The Secret of Grey Walls. London: George Newnes Ltd.

Schlegoff, E. (1997) Whose Text? Whose Context? Discourse and Society 10(3), 165-88

Spender, D. (1980) Invisible Women: The Schooling Scandal. London: Women's Press

Spender, D. (1985) Man Made Language $2^{\text {nd }}$ ed. London: Routledge and Kegan Paul

Stephens, J. (2002) “A Page Just Waiting To Be Written On”: Masculinity Schemata and the Dynamics of Subjective Agency in Junior Fiction. In J. Stephens (ed) Ways of Being Male (pp. 38-54) Abingdon: Routledge

Stoney, B. (1986) Enid Blyton, A Biography, $2^{\text {nd }} e d$. London: Hodder and Stoughton

Swann, J. (2011) Yes, But Is It Gender? In J. Coates and P. Pichler (eds) Language and Gender, A Reader $2^{\text {nd }} \mathrm{ed}$. (pp. 551-568) Chichester: Wiley-Blackwell

Talbot, M. (2010) Language and Gender $2^{\text {nd }}$ ed. Cambridge: Polity Press

Tannen, D. (1986) That's Not What I Meant. New York: Dent

Weatherall, A. (2011) Gender Relevance in Talk-in-Interaction and Discourse. In J. Coates and P. Pichler (eds) Language and Gender, A Reader $2^{\text {nd }}$ ed. (pp. 548-550) Chichester: Wiley-Blackwell

West, C. and Zimmerman, D. (1983) Small insults: a study of interruptions in cross-sex conversations between unacquainted persons. In B. Thorne, C. Kramarae and N. Henley (eds) Language, Gender and Society. Rowley, MA: Newbury House

Zimmerman, D. and West, C. (1975) Sex roles, interruptions and silences in conversation. In B. Thorne, C. Kramarae and N. Henley (eds) Language and Sex: Difference and Dominance (pp. 105-29) Rowley, Mass: Newbury House 